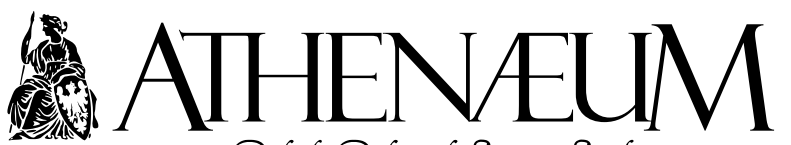

Polish Political Science Studies

Polskie Studia Politologiczne

vol. $68(4) / 2020$, pp. $86-98$

DOI: 10.15804/athena.2020.68.07

www.athenaeum.umk.pl

ISSN 1505-2192

\title{
SIGNIFICANCE OF CITIZENS' POLITICAL CULTURE IN THE PROCESS OF DEMOCRATIZATION: A CASE STUDY - UKRAINE
}

\author{
ZNACZENIE OBYWATELSKIEJ KULTURY POLITYCZNEJ \\ W PROCESIE DEMOKRATYZACJI. \\ STUDIUM PRZYPADKU - UKRAINA
}

Vladyslav Myroniuk*

\begin{abstract}
The beginning of the $1990^{\text {s }}$ was a time of geopolitical transformations. The collapse of the Soviet Union led to formation of new states that entered the path of democratization, and Ukraine was not an exception. Despite almost 30 years of independence, Ukraine remains a weak democracy. The reason of that, along with other problems, are peculiarities of political culture of citizens. Notwithstanding, weakness of political culture could be changed into the greatest advantage in the process of maturing of democracy in Ukraine.
\end{abstract}

Keywords: Ukraine; democratization; political culture; state consolidation; citizens' consolidation
Początek lat 90. to czas przemian geopolitycznych. Upadek Związku Radzieckiego doprowadził do powstania nowych państw, które weszły na ścieżkę demokratyzacji - Ukraina nie była wyjątkiem. Pomimo prawie 30 lat niepodległości Ukraina nadal posiada słabą demokrację. Powodem tego, wraz z innymi problemami, jest specyfika obywatelskiej kultury politycznej. Mimo to słabość kultury politycznej może być zmieniona w największą zaletę w procesie dojrzewania demokracji na Ukrainie.

Słowa kluczowe: Ukraina; demokratyzacja; kultura polityczna; konsolidacja państwa; konsolidacja obywatelska

* Maria Curie-Skłodowska University in Lublin, Faculty of Political Science and Journalism. 


\section{INTRODUCTION}

Phenomena like state and political regime continue to be relevant subjects of research, especially significant in countries that are facing challenges in proper functioning of political regime. This article analyses significance of citizens' political culture in the process of democratization on an example of Ukrainian Soviet Socialist Republic.

The research question implies to determine the ways to enhance democratization and state consolidation in Ukraine. Hypothesis of the research is based on the assumption, strengthening of an independent, strong and stable democratic state largely depends on political culture and consciousness of citizens, their mentality and patriotism. Case study research was chosen for the analysis. In the research, there were applied qualitative and quantitative methods. Applied theories are constructivism and structuration. In constructivism, a core emphasis is given on interpretation, and impact of socially constructed ideas, norms and culture (Parsons, 2018, pp. 76-79). Structuration or structural dualism theory is based on an idea of reproduction in social systems and the relationship between "structure" (set of rules and resources) and "agency" (actor). In other words, citizens contribute to establishment of structure, and they are limited by the rules and resources that are imposed by structure on them (Giddens, 2003, pp. 30-67).

Democratization processes are well presented in works of such scholars like Dankwart A. Rustow, Samuel P. Huntington, Guillermo O’Donnell, Philippe Schmitter, Thomas Carothers, Francis Fukuyama, Adam Przeworski, Taras Kuzio, Larry Diamond and others. Among scholars of political culture outstanding contribution to the development of discipline had been done by Gabriel A. Almond, Sidney Verba, Lucian Pye, Ronald Inglehart, Walter Rosenbaum and others.

\section{STATE CONSOLIDATION AND RESEMBLANT CONCEPTS}

Rustow in the article Transitions to Democracy: Toward a Dynamic Model presented a concept of transition, which he referred to a change in political regime. Rustow proposed one precondition and three-phase model of transition from autocratic to democratic regime. The precondition is national unity, which means that the vast majority of citizens firm democracy. In preparatory phase, an authoritarian regime is cracking down, and eventually collapse. In decision phase, a democratic regime is established instead of previous one. In the habituation 
phase, democratic regime is further developed and consolidated (Rustow, 1970, pp. 350-361).

O'Donnell and Schmitter referred to transition as an interval between one political regime and another. On one side, transitions are delimited by launching of the process of dissolution of an authoritarian regime, and on the other, by establishment of some form of democracy, the emergence of a revolutionary alternative, or the return to some form of authoritarian rule (O'Donnell \& Schmitter, 2013, p. 5).

Samuel P. Huntington in his book The Third Wave: Democratization in the Late Twentieth Century introduced a term of 'democratization wave', defined as a group of transitions from non-democratic to democratic regimes that happened in particular period of time when a number of democratic transitions prevailed over non-democratic ones. Huntington divided democratization into three waves: first wave (1828-1926), first decline (1922-1942); second wave (1943-1962), second decline (1958-1975); third wave (1974-up today) (Huntington, 2003, p. 26).

Carothers unfolded transition process in a set sequence of stages. 1. Opening, liberalisation of ruling dictatorial regime. 2. Breakthrough, collapse of the ruling regime and the emergence of a new, democratic one. 3. Consolidation, a slow process of maturing of democratic forms into substance through the reform of state institutions, strengthening of civil society, the regularization of elections and habituation of society to democratic regime. Carothers criticized Huntington's concept of democratization waves. Most of the states of the third wave failed to establish well-functioning democratic regimes, and did not attempt to deepen or develop democracy. For example, at the opening stage, Belarus, Uzbekistan, Turkmenistan clearly failed, and then returned back to authoritarian regimes. Of the nearly 100 states considered as transitional in recent years, only a relatively small number - about 20 - were on route of being well-functioning democracies; in this group, among others, leading position belongs to states like Poland, the Czech Republic, Hungary, and Estonia. The rest of the states are struggling with challenges on the way to establishing well-functioning democratic regime. Scholars and political analysts have coined a term of 'qualified democracy' to characterize states that come to standstill in democratic regime consolidation. To the group of qualified democracy belong formal democracy, semi-democracy, pseudo-democracy, weak democracy, partial democracy, virtual democracy, façade democracy, and illiberal democracy (Carothers, 2002, pp. 7-9). 
Numerous views on the topic of democratic transition colligate in three general steps. Establishment of democratic regime requires previous liberalisation of whether totalitarian or authoritarian regime. Likewise, political culture and consciousness of political elites and citizens is crucial. Primary reason for change is a desire of a better life in economic, socio-cultural and political terms.

Second stage is establishment of a new democratic regime. The timeline of this stage is considered from the momentum of completion of the old regime to the adoption of a democratic constitution. On average this stage lasts 5-7 years.

Third stage of democratic transition is achieved when democratic values are rooted in political culture of citizens and state institutions fulfil their responsibilities given to citizens and documented in constitution. However due to peculiarities of national culture and political culture of citizens, in different states this stage lasts longer than in others. Furthermore, at this stage the real face of established democratic regime is shown, whether it will be well-functioning democracy or qualified democracy. Thus, culture and political culture of citizens is important.

In the year 1963, together with Verba, Almond defined political culture as specific political orientation, perception of political guidelines for the political system and guidelines of own role in the system. The political culture of a nation is understood as distribution of patterns of orientation toward political objects among the nation's members (Almond \& Verba, 1963, pp. 13-15). Generally, the concept of political culture is based on the assumption that cultural factors determine behaviour and actions of citizens and thus influence structure. Schematically it is presented in Figure 1 (Fuchs, 1998, pp. 5-6).

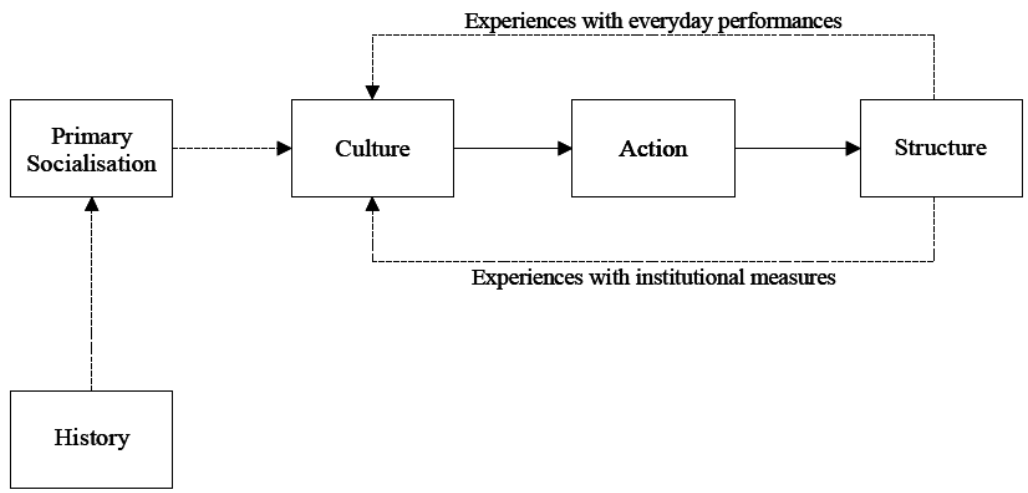

Figure 1. Basic Causal Assumptions of the Concept of Political Culture

Source: Fuchs, 1998, p. 5. 
Formation of political culture in each society depends on many factors, including history, national culture, interests of various social groups, geopolitics, and ideology. Political culture is a part of culture that is responsible for political behaviour, political activity, and political awareness of people. Political culture is a connector between policy and an individual (Putnam, Leonardi, \& Nonetti, 1993, pp. 3-6). In other words, primary function of political culture is determination of political action patterns adjusted to peculiarities of each political system (Mel'nikov \& Sokol, 2011, pp. 22-29).

In order to establish stable democratic system, it is equally important for the state to be consolidated. State consolidation is a process of strengthening bonds between citizens and authorities, which results in political stability and robust development. In the process of state consolidation there is subdivision into two dynamic processes, i.e., consolidation of citizens and consolidation of authorities.

Citizens' consolidation could be divided into permanent and temporary. Permanent citizens' consolidation is an allegiance given by majority of citizens, legitimizing ruling authorities. Consequently, citizens' awareness on political matters is a basis for robust democracy, in which political pathology, e.g., oligarchy, kleptocracy, and other, is diminished or absent.

Sustenance of permanent citizens' consolidation requires existence of an appropriate educational system and educational programs. Education fulfils several decisive goals: transfer of knowledge and skills; upbringing of national and political culture to youth. The higher the awareness and political culture of citizens, the wider and more stable is foundation of legitimacy given to authorities. This is especially valuable in well-working democratic regimes where citizens have an ability to directly influence the structure.

Temporary citizen's consolidation refers to citizens' reactions on certain occurrences happening in their socio-political environment. This type of consolidation may have both natural and man-made reasons. For instance, to the group of temporary consolidating may be included reasons such as:

- Necessity for socio-economic improvements, e.g., workers' strikes, demonstrations, protests, revolutions;

- Necessity to reach a common consensus, e.g., local or national elections;

- Unexpected occurrences, e.g., climate calamity, military invasion.

Changing nature of temporary consolidation demonstrates a dynamic curve in which society is presented as an entity (Figure 2). From another approach to the society as a group of actors that reciprocally interact in certain framework, 


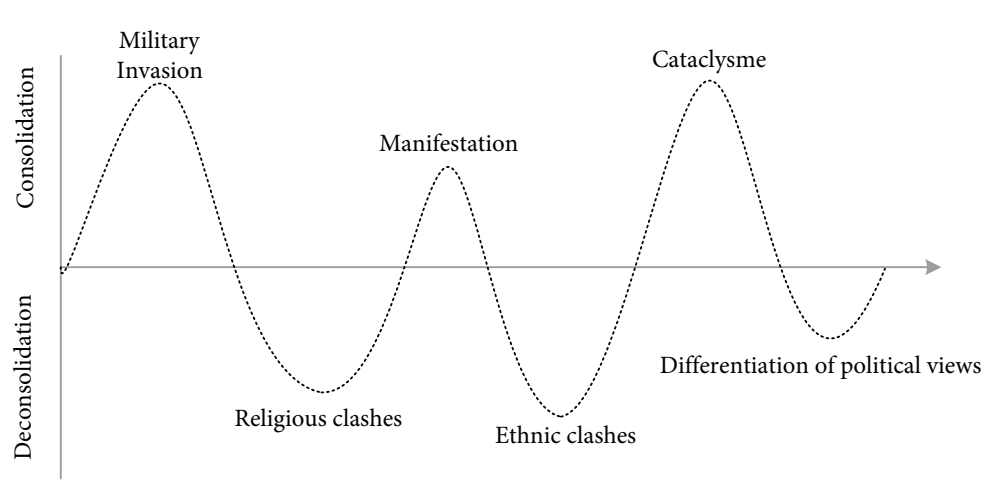

Figure 2. Temporary Citizen's Consolidation in a Form of Dynamic Curve Source: author's own elaboration.

man-made deconsolidating factors toward one group could have consolidating significance to other.

Deriving from Max Weber's definition of state authorities as universal, independent, public bodies that monopolize legitimate use of power within a clearly bounded territory (Weber, 1990, p. 318), state authorities consolidation is a process of strengthening carried out by political elites, in order to obtain a monopoly not only on the use of violence, but it also can be attributed to the fight against factors that weaken state authorities, e.g., corruption, separatist movements, etc. Consolidation of state authorities can be initialized by both domestic and foreign triggers, e.g., restoration of authorities or strengthening of their position can be authorized by the UN.

\section{ROLE OF CITIZENS' CONSOLIDATION IN DEMOCRATIZATION PROCESS}

The three-phase democratic transition process could be demonstrated on the example of former Soviet Republics and particularly Ukrainian Soviet Socialist Republic. What is worth emphasizing is that despite of the great socio-economic potential of Ukraine after the dissolution of the Soviet Union, Ukrainian political elites have not managed to engrain democratic values in political culture of Ukrainian citizens and to consolidate the state. 
Liberalisation and collapse of the Soviet Union (1985-1991). Since 1985, Mikhail Gorbachev, the Secretary General of the Soviet Union, guided Soviet state with the principles of a new reformatory policy, liberalisation of sociopolitical life, expansion of freedom of speech, and even attempted to democratize the Communist Party of the Soviet Union (CPSU). In the second half of 1989, after the summit of Soviet Deputies, political confrontation between advocates of socialist and reformist way of the Soviet Union's future sharply escalated. As a consequence of liberalisation in the Soviet Republics, there appeared nationalistic and democratic movements, some of them, especially in the Baltic republics, prioritized independence and withdrawal from the Soviet Union. In 1990, Lithuanian Soviet Socialist Republic was the first that proclaimed its independence. December 26, 1991, was the day when Soviet Union ended (Halushko, n.d.).

Popular mobilisation in case of the former Soviet Republics differed depending on the country; the greatest popular mobilisation took place in the Transcaucasian republics and the Baltic states. Belarus and Central Asia had very little mass mobilisation and political elites remained largely pro-Russian. Ukraine was in the middle of these two extremes of elite detachment (Kuzio, 2001, pp. 28-29). Bulk of Ukrainian political elites in $1990^{\text {s }}$ consisted of former CPSU members, and so-called 'red directors' (the term used in regard to the directors of large factories). Ukrainian Soviet Socialist Republic smoothly changed one regime to another. However, major posts were still occupied by communists. Generally, after the dissolution of the Soviet Union, newly established states faced not only democratization processes but also economic transition, which at the beginning resulted in deep economic crisis.

Democratic regime establishment (1991-1996). On December 1, 1991, a referendum took place on Ukrainian independence: $90.32 \%$ of all voters (i.e., of $84.18 \%$ of people who had the right to participate) supported Ukrainian state independence, thus domestically legitimated the Act of Declaration of Independence of Ukraine on August 24, 1991 (Androshchuk, n.d.). Temporary consolidation was a key here; the political activism of political elites and socially active people caused a resonance in society and affected the permanent consolidation of people. June 28, 1996 was the date when the Constitution had been adopted by the Ukrainian Parliament. On this date, the democratic regime in Ukraine was finally established.

Habituation phase has been going on since 1996 up to this day, and Ukrainian democracy is still far from consolidated. Ukraine's still facing numerous challenges, most important of them are, e.g.: 
- Peculiarities of citizens' political culture;

- Decisive majority of political elites originated from communist environment;

- Privatisation process led to foundation of oligarchs (people who gained their wealth in a way of depredation and privatisation of state enterprises);

- Lack of universally accepted national idea;

- Weak civil society sector;

- Lack of stable and lasting party system;

- Russian hostile actions against Ukraine.

Ukrainians as an ethnicity consist $77.8 \%$ of total population in Ukraine, according to the national census that took place in 2001 (Derzhavnyy komitet statystyky Ukrayiny, n.d.). Despite of dominant position amongst ethnic groups, the political culture of Ukrainians is far from homogeneous and varies significantly by regions, which is a challenging problem for state consolidation. Political culture of Ukrainians is characterized by legal and political nihilism, low level of civil society participation, lack of trust and respect to state authorities, and broad level of disrespect to politicians. According to the social survey conducted by Razumkov Centre concerning the issue of trust of citizens to the authorities and politicians (survey was conducted in period of October 30 to November 5, in survey took part 2020 respondents older than 18 years old from all regions of Ukraine, with exception of temporary occupied territories), highest level of distrust have: official establishment $79 \%$, the parliament $76 \%$, judicial system (in general) $75 \%$, the government $75 \%$, political parties $73 \%$, the president $60 \%$. In the same survey the highest levels of trust have: the ministry of defence $66 \%$, the church $62 \%$, the mayor of town (the head of village) in which respondent live $54 \%$, the town council (or the village council) 50\% (Razumkov Centre, 2020).

Preliminary results of local elections that were held on October 25, 2020, proved the statistical data presented by Razumkov Centre. In a scale of Ukraine, about $16 \%$ of deputies to the councils of localities having over 10 thousand residents came from local non-party candidates, in comparison to the large political parties that passed 5\% census and came to the parliament with the result of about $45 \%$, and the rest to the other parties. About $96 \%$ of deputies to the councils of localities that have less than 10 thousand residents came from the group of local non-party candidates (Tsentral'na vyborcha komisiya, 2020). Lack of trust to central authorities and effects of decentralisation reform may deepen regionalization in Ukraine. 
One of the possible reasons of trust to regional authorities could be decentralization reform, which extended competencies of mayors and increased local budgets. It may be also caused by distrust to large political parties and tiredness of core politicians as well. Society is looking for real political leaders that could withdraw the state from economic and political crisis. Volodymyr Zelensky was that hope - in the 2019 Presidential Elections Ukrainians voted for him mostly for the above reason. Despite problems with maturing of democracy in Ukraine, perspective of return to the authoritarian regime is barely possible due to regional splits (confessional, ideological, and political) that are present in Ukraine between macro-regions.

Besides of economic development, Ukrainian political elites should pay attention to the development and financing of citizens' political education, and a long-term strategy should be elaborated. Citizens should defend their interests and demand from regional representatives to present their interests in the parliament. Basing on the decentralization policy, local authorities together with non-governmental organizations (NGOs) should conduct educational programs aimed at educating people on political and legal issues. On January 1, 2019, 84 608 NGOs were registered in Ukraine. Local authorities in cooperation with NGOs could make a necessary impact on society that in future results with higher awareness on political matters and improvement of citizens' political culture (Heletiy, 2019, p. 27). According to the survey from the year 2018, 42\% of non-governmental organizations considered their main problem to be the lack of interest from the government and business (31\%) (Bekeshkina, 2019, p. 8).

Montesquieu noted that laws should correspond to peculiarities of nation to whom they are established, and also in very rare cases laws of nation could be suitable to another people (Myn'kovych-Slobodyanyk, 2015, p. 29). Therefore, there is a review of laws and to the extent possible, laws should correspond with peculiarities of national and political cultures. It might support the process of laws implementation.

In this sense, oligarchs are a significant obstacle. Hellman, Jones and Kaufmann (2003) in their publication Seize the State, Seize the Day: State Capture and Influence in Transition Economies distinguished 'seizing the state' as a proactive kind of corruption, which happens purposely in order to get influence on state institutions in favour of businessmen. Basic objectives behind the seizure of state are protection of property in the states where state authorities are weak, and also monopolisation of certain economic sectors. According to the research, in Ukraine all types of state seizure are present, namely the seizure of regulators, 
state-owned enterprises and budget flows (Yablonovs'kyy \& Zakharov, 2017,pp. 6-33). Therefore, in order to consolidate the state, diminishing the impact of oligarchy should be an inevitable priority for the state officials and citizens.

\section{WAYS TO ENHANCE DEMOCRATIC AND STATE CONSOLIDATION}

State authorities have resources and abilities to influence society and to strengthen it in several ways. Below there are presented samples of methods for achieving important objectives for democratic state consolidation.

Objective - strengthening of permanent citizens' consolidation, methods:

- Encourage businessmen (via tax reliefs) to financially support initiatives originated from proactive citizens and NGOs;

- Ministry of Education should elaborate educational programs that focus on rise of national and political culture of citizens, in order to diminish social contradictions;

- Implementation of state programs to combat social maladies, like alcoholism, drug addiction, etc.

Objective - consolidation of state institutions, methods:

- Diminishing the impact of non-state cells of power, oligarchs, separatists, banditry, etc.;

- Ensuring proper functioning of three branches of power;

- Adoption of popularly accepted national idea as a guide for state existence;

- Improving quality of regional governing in peripheral borderland regions.

Objective - increase of trust to the authorities, methods:

- Formation and functioning according to transparent electoral legislation;

- Upkeep of transparent system of public procurement;

- Ensuring freedoms and rights of citizens, according to national legislation and international conventions;

- Lustration of corrupt officials in the state apparatus. 


\section{CONCLUSIONS}

The third wave of democratization can be considered as successful only relatively, given that out of nearly 100 states that were included in this wave, only 20 have built successful democratic regimes. One of the reasons for the failure of democratic regimes in many countries is a lack of correlation between democratic values and political culture of citizens.

Ukraine was one of the third wave states, but for almost 30 years of independence, it has not been able to fully pass the three stages of democratization. Ukraine faces numerous problems that are equally important. The article pays special attention to political culture and its significance in the process of democratization. The main thesis is that the political culture of citizens could be modified through appropriate educational programs, and spreading of awareness via NGOs and media. Even the existing differences between macro-regions can be overcome. Not by forcible acceptance of a universal vision on political culture, but by gently emphasizing differences and tolerance for them with the help of generally accepted national idea, which, for example, can be the creation of a strong and prosperous state of Ukraine. The one Ukrainians have never had.

\section{ReFERENCES:}

Almond, G.A., \& Verba, S. (1963). An Approach to Political Culture. In: G.A. Almond, G.A., \& S. Verba, The Civic Culture: Political Attitudes and Democracy in Five Nations (pp. 3-42). Princeton, New Jersey: Princeton University Press. DOI: 10.2307/j. ctt183pnr2.4.

Androshchuk, O.V. (n.d.). Referendum Pershoho Hrudnya 1991 [Referendum of 1 December 1991]. Institute of History of Ukraine, National Academy of Sciences of Ukraine. Retrieved from: http://www.history.org.ua/?termin=Referendum.

Bekeshkina, I.E. (2019). Hromadyany prohromadyans'ke suspil'stvo: shcho zminylosya? [Citizens about Civil Society: What Has Changed?]. In: O.A. Korniyevs'kyy, Yu.A. Tyshchenko, \& V.M. Yablons'kyy (eds.). Hromadyans'ke suspil'stvo Ukrayiny: polityka spryyannya ta zaluchennya, vyklyky ta transformatsiyi [Civil Society of Ukraine: Promotion and Engagement Policy, Challenges and Transformations] (pp. 13-24). Kyiv: National Institute for Strategic Studies.

Carothers, T. (2002). The End of the Transition Paradigm. Journal of Democracy, 13(1), 5-21. DOI: 10.1353/jod.2002.0003.

Derzhavnyy komitet statystyky Ukrayiny [Ukrainian State Statistics Committee] (n.d.). Pro kil'kist' ta sklad naselennya Ukrayiny za pidsumkamy Vseukrayins'koho perepysu naselennya 2001 roku [About the Number and Composition of the Population of 
Ukraine Based on the Results of National Population Census of 2001]. Retrieved from: http://2001.ukrcensus.gov.ua/results/general/nationality/.

Fuchs, D. (1998). The Political Culture of Unified Germany. Discussion Papers, FS III 98-204, 1-45. Berlin: WZB Berlin Social Science Center.

Giddens, A. (2003). Stanowienie społeczeństwa: zarys teorii strukturacji. Poznań: Zysk i S-ka.

Halushko, K.Yu. (n.d.). Rosiya [Russia]. Institute of History of Ukraine, National Academy of Sciences of Ukraine. Retrieved from: http://www.history.org. ua/?termin=Rosiia.

Heletiy, M.M. (2019). Stan ukrayins'kohohromadyans'koho suspil'stva: zahal'ni tendentsiyi [State of Ukrainian Civil Society: General Trends]. In: O.A. Korniyevs'kyy, Yu.A. Tyshchenko, \& V.M. Yablons'kyy (eds.). Hromadyans'ke suspil'stvo Ukrayiny: polityka spryyannya ta zaluchennya, vyklyky ta transformatsiyi [Civil Society of Ukraine: Promotion and Engagement Policy, Challenges and Transformations] (pp. 25-35). Kyiv: National Institute for Strategic Studies.

Hellman, J.S., Jones, G., \& Kaufmann, D. (2003). Seize the State, Seize the Day: State Capture and Influence in Transition Economies. Journal of Comparative Economics, 31(4), 751-773. DOI: 10.1016/j.jce.2003.09.006.

Huntington, S. (2003). Tret'ya volna. Demokratizatsiya $v$ kontse XX veka [The Third Wave: Democratization in the Late Twentieth Century]. Moscow: ROSSPEN.

Kuzio, T. (1998). Ukraine: State and Nation Building. London: Routledge.

Mel'nikov, A.P., \& Sokol, S.F. (2011). Politicheskaya Kultura $v$ Zhizni Obshchestva [Political Culture in Life of Society]. Minsk: Belarusian State University.

Myn'kovych-Slobodyanyk, O.V. (2015). Pravova i politychna kul'tura v umovakh polityko-pravovoyi transformatsiyi suspil'stva [Legal and Political Culture in the Context of Political and Legal Transformation of Society]. Chasopys Kyyivs'koho universytetu prava [Journal of the Kyiv University of Law], 4, 28-31.

O'Donnell, G., \& Schmitter, P.C. (2013). Transitions from Authoritarian Rule. Vol 4: Tentative Conclusions about Uncertain Democracies. Baltimore, Maryland: Johns Hopkins University Press.

Parsons, C. (2018). Constructivism and Interpretive Theory. In: V. Lowndes, D. Marsh, \& G. Stoker (eds.). Theories and Methods in Political Science (4 ${ }^{\text {th }}$ ed.) (pp. 75-91). London: Palgrave.

Putnam, R., Leonardi, R., \& Nonetti, R. (1993). Introduction: Studying Institutional Performance. In: R. Putnam, Making Democracy Work: Civic Traditions in Modern Italy (pp. 3-16). Princeton, New Jersey: Princeton University Press. DOI: 10.2307/j. ctt7s8r7.6.

Razumkov Centre (2020, November 10). Otsinka hromadyanamy sytuatsiyi v krayini, riven' doviry do sotsial'nykh instytutiv tapolitykiv, elektoralni oriyentatsiyi hromadyan (zhovten'-lystopad 2020r.) [Citizens' Assessment of the Situation in the Country, the Level of Trust in Social Institutions and Politicians, Electoral Orientations of Citizens (October-November 2020)]. Retrieved from: https://razumkov.org.ua/ napriamky/sotsiologichni-doslidzhennia/otsinka-gromadianamy-sytuatsii-v- 
kraini-riven-doviry-do-sotsialnykh-instytutiv-ta-politykiv-elektoralni-oriientatsiigromadian-zhovten-lystopad-2020r.

Rustow, D.A. (1970). Transitions to Democracy: Toward a Dynamic Model. Comparative Politics, 2(3), 337-363. DOI: 10.2307/421307.

Tsentral'na vyborcha komisiya [Central Election Commission] (2020, October 25). Mistsevi vybory 2020 [Local Elections 2020]. Retrieved from: https://www.cvk.gov. ua/pls/vm2020/pvm002pt001f01=695pt00_t001f01=695.html\#.

Weber, M. (1990). Izbrannyye proizvedeniya [Selected Works]. Yu.N. Davydov (ed.). Moscow: Progress.

Yablonovs'kyy, D., \& Zakharov, A. (2017). Zvil'nyty zakhoplenu derzhavu Ukrayina [Release the Captured State of Ukraine]. Kyiv: Centre for Economic Strategy. 